\title{
Private University Lecturer's Professional Commitment In Jakarta
}

\author{
Marisa Permatasari \\ Universitas Negeri Jakarta \\ Email: marisapermatasari_7647111168@mhs.unj.ac.id \\ Dedi Purwana \\ Universitas Negeri Jakarta \\ Email: dpurwana@unj.ac.id \\ Maruf Akbar \\ Universitas Negeri Jakarta \\ Email: maruf.akbar@unj.ac.id
}

\begin{abstract}
This study aims to analyze the effect of transformational leadership, academic culture, self engagement on lecturer's professional commitment of private university in Jakarta. A quantitative approach were used in the study. Data were analyzed from 212 lecturers of B-Accreditation private universities in Jakarta using Structural Equation Modelling (SEM). The findings delivers two things; First, there were positive and significant effect of transformational leadership on lecturer's professional commitment; self - engagement on lecturer's professional commitment; transformational leadership on academic culture; academic culture on self-engagement. Second, there were no significant effect of academic culture on lecturer's professional commitment; transformational leadership on self-engagement.
\end{abstract}

Keywords: professional commitment, transformational leadership, academic culture, self engagement

Received: 20 August 2020 ;

Accepted: 7 September 2020 ;

Publish; December 2020.

\section{How to Cite:}

Permatasari, M., Purwana, D., Akbar, M. (2020). Private University Lecturer's Professional Commitment In Jakarta. International Journal of Human Capital Management, 4 (2), 64-77. https://doi.org/10.21009/IJHCM.04.02.07 


\section{INTRODUCTION}

Education shaped the way of people contribute to the development of a nation and it can be achieved through an education institution (Awang, Ahmad, \& Zin, 2010). A success higher education institution is capable of providing the best teachings, researches and services in order to satisfy the student needs and form the best student graduates (Endro, Budiyanto, \& Suhermin, 2017; Siregar, Lumbanraja, \& Salim, 2016; Xiao \& Wilkins, 2015). One of the key players is the educator or lecturer who contributes their teachings and researches by keep updating their knowledge and delivers it best for their students (Awang et al., 2010; Gupta \& Nain, 2015). As Dorenkamp and Ruhle (2018) stated that lecturer needs to fulfilled their academic duties such as research, teaching, publishing papers and also community service. In Indonesia, these academic duties are commonly known as "Tridharma Perguruan Tinggi". In order to achieve the ideal performance of Tridharma Perguruan Tinggi, a lecturer has to be an excellent lecturer. Wood and $\mathrm{Su}$ (2017) emphasized that an excellent lecturer is someone who is committed and dedicated to their profession. A lecturer who has a low level of professional commitment meaning that they have low feeling of attachment and appreciation towards their profession (Jabeen, Khan, \& Islam, 2019). Shukla (2014) mentioned that teaching is not just an occupation but there is more to it for a bigger picture, therefore a lecturer needs to have a professional commitment; it is a feeling of dedication towards their profession. Professional commitment of lecturer has been recognized as one of the most important factor for the future success of education and its institution (Thoker, 2017). Professional commitment reflecting the person's attitude to their profession, and usually a person whose committed their profession, they motivate themselves in order to keep up with their profession development (Mitchell, Boyle, \& Von Stieglitz, 2018; Shoaib \& Khalid, 2017).

Over the years, lecturer's professional commitment had not been fulfilled ideally. As it is shown by Widawati, Styani dan Nadya (2010) in their study of professional commitment of lecturers in a university which had found that $70 \%$ of lecturers were commited to their teaching duties, $19 \%$ were commited to their research duties and the rest were the community service. Another study also concluded that the performance of lecturer's Tridharma Perguruan Tinggi was majorly in teaching but only acquired a fair result on research and community service (Bungai \& Perdana, 2018; Istambul, 2019; Nur'aeni, 2011). A similar result was obtained by a pre-survey conducted through a sample of 35 lecturers from B-accreditation higher education institution in Jakarta regarding the fulfillment of Tridharma Perguruan Tinggi and the results found that $67 \%$ of lecturers were not fulfilled their research and publishing papers duties, $51.7 \%$ were not fulfilled their community service duties and lastly $35.5 \%$ were not fulfilled their teaching duties. According to those studies above, it revealed that most of lecturers were only focused on their teaching duties because it is the most basic duty to carry out and the proportion provided by the campus is heavier to teaching compared to the research duties and community service duties that were not done optimally, It was due to some aspects such as they find it difficult in doing it, the campuses does not support to facilitate research or community service, it is quite costly and also it is not a priority for them because being a lecturer is considered as a secondary profession.

Professional commitment reflecting their work performance where they need to have creative thinking, innovation and contribute their knowledge and values for the development of their students (Shahdan, Ghani, \& Elham, 2012). There are other factors that may contribute to this professional commitment of lecturer matter. Due to that, leadership style may play a role to enhancing the commitment of individuals in their institution (Ochugudu, Ipuele, \& Aondoaseer, 2013). Transformational leadership style may facilitate lecturer commitment and capacities to reach the goals through the leader behavior such as setting clear direction, brings charisma, motivation, inspiration, developing people and redesigning the organization to fulfilled the lecturers' needs (Para-González, Jiménez-Jiménez, \& Martínez-Lorente, 2018; Selamat, Nordin, \& Adnan, 2013). A study by Islam (2019) revealed a direct significant and positive effect of transformational leadership on lecturer's professional commitment; it is believed that transformational leader formed the lecturer's commitment and encouraged them to contribute to their fullest potential for the development of education institution. On the other hand, Darmawati (2013) established an insignificant effect of leadership on professional commitment. 
Academic culture also may have an effect on professional commitment, a regression analysis study by Setyaningsih (2017) concluded a significant effect academic culture on professional commitment of university lecturers. Another path analysis study on private higher education institution lecturer by Murniarti (2014) stated a significant and positive effect of academic culture on work commitment. On the contrary, Awan, Mahmood dan Idrees (2014) based on their ANOVA result discovered insignificant effect of culture on commitment. Academic culture creating the system of work that built on norms, value, organization standards and rules (Dirwan, 2015).

As it is stated by Yalabik, van Rossenberg, Kinnie and Swart (2015) on their regression analysis study which had concluded a significant and positive effect of engagement towards professional commitment. A similar result by Hanaysha (2016) using Structural Equation Modelling analysis, confirmed a significant and positive effect of employee engagement on organizational commitment. Being a lecturer is being engaged to a profession that need the person's dedication, vigor, patience and their willingness to share their knowledge and educate other. Those positive attitude will brings the best to put deeper in their academic duties as well as to shape their commitment towards their profession (Arifin, Troena, Djumahir, \& Rahayu, 2014). On the basis of past studies, this present study was undertaken to examine and analyze the effect of transformational leadership, academic culture, self - engagement on private university lecturer's professional commitment.

\section{LITERATURE REVIEW}

\section{Professional commitment}

According to Shukla (2014) professional commitment is a person's willingness to dedicate themselves to their profession. Furthermore, Becker, Kernan, Clark and Klein (2018) defined professional commitment as one's motivation by putting their best ability and skills in order to develop their professional growth. Gill dan Kaur (2017), professional commitment is the degree of person's acceptance and involvement to the profession by putting their best effort to develop their teaching profession. More over Arjunan and Balamurugan (2013) explained professional commitment is an enthusiasm to involve in the work related; in this case is to be involved in teaching and their aspects. Shamina (2014), professional commitment of lecturer is a person's belief in the teaching goals and values, dedicated efforts and the desire to maintain their teaching membership. According to Thoker (2017), professional commitment of lecturer is define as one's feeling of dedication towards their teaching profession which not only encouraged for the development of the students but also their professional growth. Attri dan Devi (2017) revealed that professional commitment can be improved through activities that support teaching professionalism such as seminars, workshop, conference, research, compensation and also work environment. Cho dan Huang (2012) mentioned professional commitment encouraged person's belief and acceptance regarding the teaching profession therefore it boost efforts to carry out the duties of the profession and loyalty to the profession. Tansakul (2015) stated that these aspects such as value, dignity, responsibility, willingness, benefit and alternative are reflecting the profession commitment. Overall, professional commitment of lecturer is the person's (lecturer) willingness to perform and have a certain attitude to fulfilled their duties and responsibilities.

\section{Transformational leadership}

Leadership take part as a key role in the organization to achieve goals. As it is defined by Yukl (2013), transformational leadership is a leadership process that driven the moral values of followers in certain ways to work beyond its capabilities. According to Northouse (2016), transformational leadership is a process that influence the followers by emphasizing emotions, values, ethics and encouraged them to reach their full potential to work their best in achieving common goals. Moreover, Kabeyi (2018) defined transformational leadership as a people-oriented leadership where the leader inspired followers to contribute their best to achieved common goals. Furthermore, $\mathrm{Ng}$ (2017) defined transformational leadership as a leader that were able to strengthen the followers' morale by giving them the meaning and belief to do the work at their 
best in achieving goals. Black (2015) revealed in the education domain, deal with changes is inevitable, transformational leadership approach is appropriate for this matter rather than transactional leadership. Li and Shi (2008) in Yu (2013) mentioned that transformational leadership are morale modeling, visionary, charisma and individualized consideration. Effective leadership has elements such as vision and goals, hands-on leadership, improvement and learning, work details and big picture (Black, 2015). Overall, transformational leadership is a leader who inspire and motivate their followers in order to deals with change and enhance their work performance.

\section{Academic culture}

According to Schein and Schein (2017), culture is a collection of routines, norms and rules which to be used as a guidance and behavior boundary. As with organizations in general, higher education institution such as university which is academically based organization will also faced with changes that occurs and university will facilitate learning to deal with the changes over time which known as academic culture (Pielmus, 2016). Therefore, academic culture can be define as shared belief, values, symbols, norms, routines and procedures which spawn from generations in the university (Pielmus, 2016). Moreover, Brick (2012) revealed that academic culture is the behavior, values and attitude presented by the academic society in the academic environment. Academic culture is the rules, norms, values, beliefs and practices that form and guide the behavior patterns of people in the university environment when carrying out academic activities such as teaching and learning, research, assessment and administration (Nayak \& Venkatraman, 2010; Sutjipto, Hidayat, \& Elizabeth, 2014; Szelényi \& Rhoads, 2013). According to Nikmah (2015) academic culture is universal culture that carried out the positive values of individual in their involvement to the academic activities. Moreover, Shen and Tian (2012) defined academic culture as the process of academic activities in the university such as teaching, research, talent development and cultural exchange which can be characterized in academic outlook, academic spirit, academic ethic and academic environment. Furthermore, Sułkowski (2016) stated that academic culture is the values, standards and academic society norms that creates the shared identity in the university. Overall, academic culture is a set of values and norms of the academic society when carry out and develop teaching and research which can become the shared identity.

\section{Self - engagement}

Engagement believed to be the key to understanding the effectiveness of human resources practices can support the performance enhancement of individuals and organization to the next level (Truss, Shantz, Soane, Alfes, \& Delbridge, 2013). An engaged individual will shown enthusiam, motivation and passion in doing their work. As stated by Saks and Gruman (2014) engagement is the person's willingness to dedicate themselves physically, cognitively and emotionally in their work. Referring to Rich, Lepine dan Crawford (2010), engagement is individual whose fully put themselves in their work physically, cognitively and emotionally. It assumed that lecturer willingly to put themselve deep in their teaching, research and any other academic activities. An engaged individually will give their best contribution to their duties and responsibilities in order to enhance the organization performance (Colquitt, Lepine, \& Wesson, 2013; Jakubik \& Vakkuri, 2015). Moreover, Klassen, Yerdelen and Durksen (2013) says lecturer who engaged will doing their duties by engaging cognitively, emotionally and their social interaction with the students or any other peers. Overall, self - engagemen is the individual actions in carrying out their duties and obligations with full responsibility shown by enthusiasm, dedication and socializing.

Past studies indicated that transformational leadership had a significant and positive effect on professional commitment (Almutairi, 2015; Endro et al., 2017; Yu, 2013). Transformation leadership encourage followers to contribute and collaborate to increase to workflow in order to achieve goals (Northouse, 2016); Committed individual able to contribute to their work or profession effectively in order to achieve the organization goals and development (Yahaya \& Ebrahim, 2016). This means that transformational leadership can enhance the levels of 
professional commitment among followers and creating a positive work outcome in achieving the common goals. Based on the discussion made above, the following proposed hypothesis:

H1: Transformational leadership has positive effect on professional commitment.

Past studies indicated that academic culture had a significant and positive effect on professional commitment (Al-Sada, Al-Esmael, \& Faisal, 2017; Azizollah, Abolghasem, \& Mohammad Amin, 2015; Setyaningsih, 2017; Zhu, Devos, \& Li, 2011). Teaching performance, supervising and research along with other aspects in academic environment shaped the academic culture of an education institution (Rosser \& Tabata, 2010). Professional commitment represent the person's willingness to contributed and devoted to their profession (Shoaib \& Khalid, 2017). Forming a positive work system of teaching and research may encourage lecturers to keep up with their duties optimally. This means that academic culture can enhance professional commitment. Based on the discussion made above, the following proposed hypothesis:

\section{H2: Academic culture has positive effect on professional commitment}

Past studies indicated that self - engagement had a significant and positive effect on professional commitment (Chandel, 2019; Eghlidi \& Karimi, 2016; Halbesleben, 2010; Hanaysha, 2016; Nazir \& Islam, 2017; Ogbuanya \& Chukwuedo, 2017; Yalabik et al., 2015). Engagement creates a harmony relationship between the individual and their work. Individual who engaged will contribute their best performance. This means engagement is able to boost individual's commitment. Therefore, based on the discussion, the following hypothesis presented:

H3: Self - engagement has positive effect on professional commitment

Past studies indicated that transformational leadership had a significant and positive effect on academic culture (Akhtar, Jalil, Farooq, Afzal, \& Awan, 2010; Awan et al., 2014; Purwana, 2015). Transformative leader are willingly to involve themselves in the organization and leads to a greater level with the right decision and direction. This means, transformational leadership can form the culture of positive values. With this discussion, the following hypothesis presented:

H4. Transformational leadership has positive effect on academic culture

Past studies indicated that transformational leadership had a significant and positive effect on self - engagement (Arifin et al., 2014; Bae, Song, Park, \& Kim, 2013; Raja, 2012; Tims, Bakker, \& Xanthopoulou, 2011). Transformational leadership motivates and inspires followers to contribute their best value thus it encourage the followers to be engaged to their duties (Tims et al., 2011). This means transformational leadership can enhance the individual to be engage through their inspiration and motivation. Based on the discussion, the following hypothesis proposed:

H5. Transformational leadership has positive effect on self - engagement

Past studies indicated that academic culture had a significant and positive effect on self engagement (Arifin et al., 2014; Suharti \& Suliyanto, 2012). Academic culture is a self-identity in a academic environment that is formed from the structure, vision, mission, decision making, governance, teaching and research which aids adapting to change, increase effectiveness and competitive advantage (Coman \& Bonciu, 2016; Lacatus, 2013). Engagement is person's eagerness to focus on the work and duties in his/her best performance in order to enhance organizational effectiveness and performance organisasi (Colquitt et al., 2013; Jakubik \& Vakkuri, 2015). This means culture defines the individual's behavior value in the organization which can enhance the engagement. Therefore, based on the discussion, the following hypothesis presented: 
H6. Academic culture has positive effect on self - engagement

\section{RESEARCH METHOD}

This study followed the quantitative approach for its methodology and data collection. The survey issued totally 248 questionnaires and received 216 questionnaires. And by eliminating the questionnaires whose answer are not serious therefore it used the effective questionnaires of 212. The questionnaires used for collecting data for this study were measured on a five-point Likert scale ranging from 1 "strongly disagree" to 5 "strongly agree. To measure professional commitment, were adapted from Tansakul, Kamata, Patarapichayatham, and Kanjanawasee (2015) consist of 6 (six) dimension. Transformational leadership were adapted and combined from Li and Shi (2008) and Black (2015) consists of 4 (four) dimension . Then, academic culture were adapted from Shen and Tian (2012) consists of 4 (four) dimension. Lastly, self - engagement were adapted from Klassen, Yerdelen dan Durksen (2013) consists of 4 (four) dimension. The collected data was then analyzed using IBM SPSS 25 and Structural Equation Modelling (SEM) on IBM AMOS 23. SEM is used due to it is regarded as a powerful statistical technique to generate more accurate and reliable findings as it was emerged as a new generation tools compared to previous studies.

\section{RESULT AND DISCUSSION}

\section{Result}

The descriptive statistics of respondents indicated that females were accounted for $56 \%$ of total response while males represented at $44 \%$. Moreover, the demographic result indicated that $1 \%$ fall in the age group less than 25 years, $28 \%$ were $25-35$ years, $33 \%$ were $36-45$ years, $23 \%$ were $46-55$ years, $14 \%$ were $56-65$ years and $2 \%$ were 65 years and above. On the education background demographic indicated that $77 \%$ had master degree and $23 \%$ had doctorate degree. And lastly, it was also found that $30 \%$ had working experience less than 5 years, $38 \%$ had experience $6-15$ years, $22 \%$ has experience $16-25$ years and $10 \%$ had experience more than 25 years.

\section{Structural Equation Modelling (SEM)}

The structural model fit test has indicated that it had met the fit criteria such as CMIN/DF 1,095; CFI 0.978; RMSEA 0.021; PClose 1.000. However, it was also found that there were non - significant direct effect of H2 and H5.

\section{H2. Academic culture on lecturer's professional commitment}

The C.R value of academic culture on lecturer's professional commitment was -0.726 ( $\leq$ 1.96) and $p$ value $\geq 0.05$, therefore it can be said this hypothesis was rejected or there was no effect of academic culture on lecturer's professional commitment.

\section{H5. Transformational leadership on self - engagement}

The C.R value of transformational leadership on self - engagement was $1.522(\leq 1.96)$ and $\mathrm{p}$ value $\geq 0.05$, therefore it can be said this hypothesis was rejected or there was no effect of transformational leadership on self - engagement.

Referring to Lomax (2010), an adequate model fit with non-significant relation had a slight meaning. Therefore, it is necessary to modify the model by trimming the non-significant relation and do another model fit test for the modified model.

\section{Modified model fit}


The modified model fit test had also met the fit criteria such as CMIN/DF 1,101; CFI 0.976; RMSEA 0.022; PClose 1.000and it was found that the rest of the relation were significant as it was shown on the model figure below:

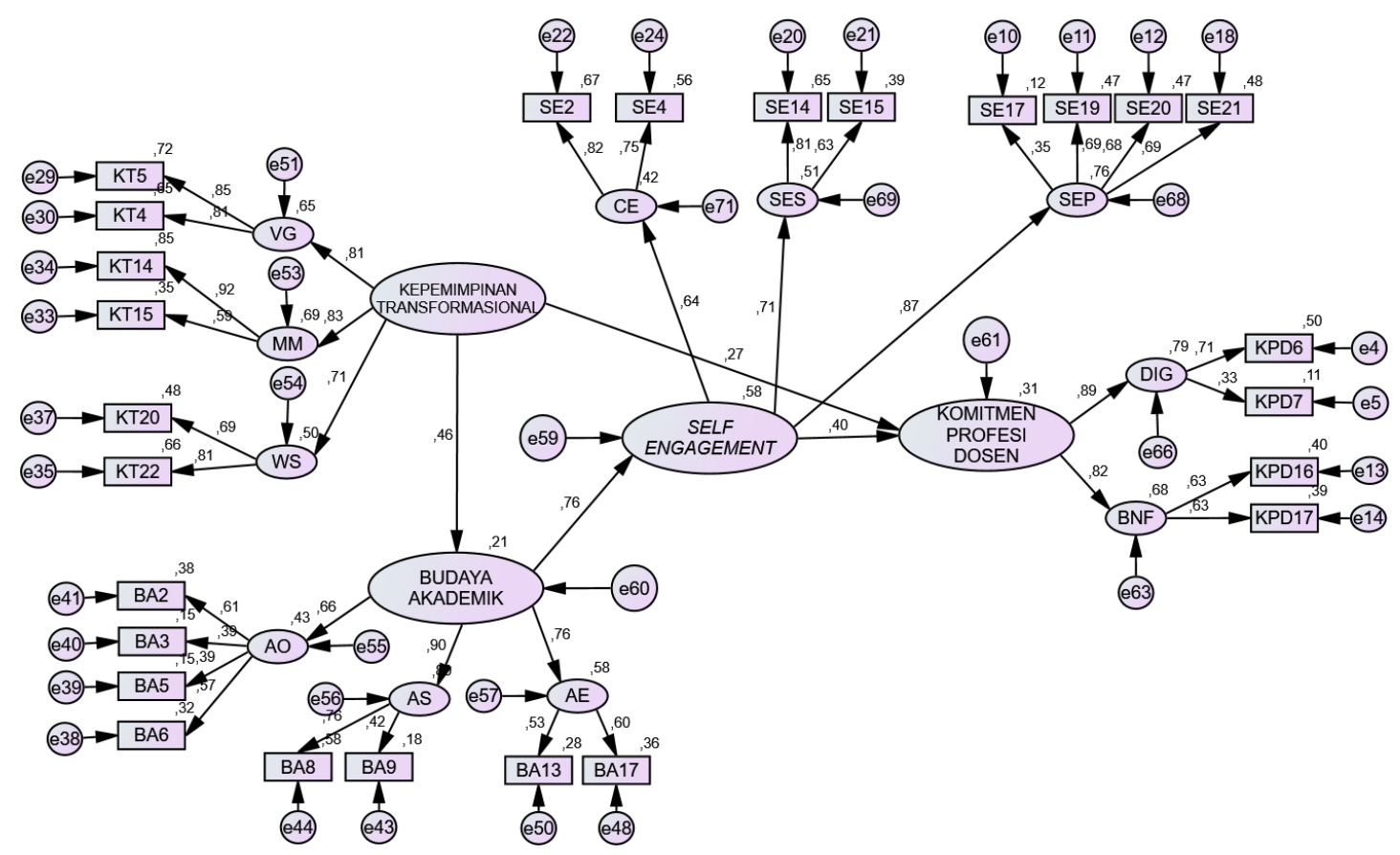

Figure 1: Modified model fit

\section{H1. Transformational leadership on lecturer's professional commitment}

The C.R value of transformational leadership on lecturer's professional commitment was 2.446 ( $\geq 1.96)$ and $p$ value $\leq 0.05$, therefore it can be said this hypothesis was accepted or there was an effect of transformational leadership on lecturer's professional commitment.

\section{H3. Self - engagement on lecturer's professional commitment}

The C.R value of self - engagement on lecturer's professional commitment was 3.267 ( $\geq$ 1.96) and $\mathrm{p}$ value $\leq 0.05$, therefore it can be said this hypothesis was accepted or there was an effect of self - engagement on lecturer's professional commitment.

\section{H4. Transformational leadership on academic culture}

The C.R value of transformational leadership on academic culture was 3.627 ( $\geq 1.96)$ and $\mathrm{p}$ value $\leq 0.05$, therefore it can be said this hypothesis was accepted or there was an effect of transformational leadership on academic culture.

\section{H6. Academic culture on self - engagement}

The C.R value of academic culture on self - engagement was $2.446(\geq 1.96)$ and $p$ value $\leq$ 0.05 , therefore it can be said this hypothesis was accepted or there was an effect of academic culture on self - engagement.

The factor loading values on each relation among variables and factor loading values on each dimension were shown on the table below: 
Table 1: Factor loading amongst variables

\begin{tabular}{llll}
\hline & & & Factor loading \\
\hline Transformational leadership & $-->$ & Academic culture & 0.460 \\
Academic culture & $-->$ & Self - engagement & 0.765 \\
Transformational leadership & $-->$ & Lecturer's professional commitment & 0.270 \\
Self - engagement & $-->$ & Lecturer's professional commitment & 0.399 \\
\hline
\end{tabular}

Table 2: Factor loading on each dimension

\begin{tabular}{lll}
\hline Variable & Dimension & Factor loading \\
\hline Lecturer's professional commitment & Dignity & 0.888 \\
& Benefit & 0.824 \\
Transformational leadership & Visionary goals & 0.807 \\
& Morale modeling & 0.832 \\
Academic culture & Wise & 0.706 \\
& Academic outlook & 0.659 \\
& Academic spirit & 0.895 \\
Self - engagement & Academic ethic & 0.760 \\
& Cognitive engagement & 0.645 \\
& Social engagement (Students) & 0.715 \\
& Social engagement (Peers) & 0.874
\end{tabular}

\section{Discussion}

There was positive and significant effect of transformational leadership on lecturer's professional commitment. It means that transformational leadership directly influence the lecturer's professional commitment. This result verifies the studies by Yu (2013), Endro, Budiyanto dan Suhermin (2017) and Almutairi (2015) which concluded a positive and significant effect of transformational leadership on lecturer's professional commitment

There was a non - significant effect of academic culture on lecturer's professional commitment. A similar result of non - significant effect of academic culture on lecturer's professional commitment was confirmed on Awan, Mahmood and Idrees (2014).

A positive and significant effect of self - engagement on lecturer's professional commitment. It means that self - engagement influence lecturer's professional commitment directly and positively. This result ties well with the studies by Yalabik et al (2015), Eghlidi and Karimi (2016), Ogbuanya and Chukwuedo (2017) which had found that self - engagement has an impact on lecturer's professional commitment.

There was positive and significant effect of transformational leadership on academic culture. It means that transformational leadership influences academic culture. This result supported the studies by Purwana (2015), Akhtar et al (2010) and Awan et al (2014) which stated that leadership has a great influence to academic culture in order to achieved shared goals.

There was a non - significant effect of transformational leadership on self - engagement. A similar result of non - significant effect of transformational leadership on self - engagement was confirmed on Kertiriasih, Sujana dan Suardika (2018). 
There was positive and significant effect of academic culture on self - engagement. It means that every increased value of academic culture will increasing the self - engagement. This result supported the studies of positive and significant effect academic culture on self - engagement by Arifin et al (2014), Suharti and Suliyanto (2012).

The findings of this study indicated that B-accreditation universities' lecturers academic culture were not directly influence lecturer's professional commitment. As Awan, Mahmood and Idrees (2014) determined in their study of that culture did not influence commitment of private university libraries employees in Pakistan. It verified that the characteristics of employees which include staff and lecturers in private universities seem dominant to have similar pattern. Culture needs to be flexible in a such working environment which they may work without feeling any burden (Habib, Aslam, Hussain, Yasmeen, \& Ibrahim, 2014) and if it cannot achieve that state then it may have a weak culture which could faces of weak commitment as well. However the influence of academic culture to self - engagement is the strongest one, and followed by the influence of self - engagement to lecturer's professional commitment. Based on that it seems that the academic culture in private universities may not be flexible but for individuals it put great effect through the academic spirits therefore it highlighted the influence of academic culture to engagement. A limitation of the current study it did not include the indirect effect between academic culture and lecturer's professional commitment through self - engagement. Although, academic culture might indirectly influence lecturer's professional commitment through self engagement. Therefore, future studies might focus on this indirect effect.

\section{CONCLUSION}

A positive and significant effect of transformational leadership on lecturer's professional commitment accounted for a factor loading of 0.270. A non - significant effect of academic culture on lecturer's professional commitment. A positive and significant effect of self - engagement on lecturer's professional commitment accounted for a factor loading of 0.399. A positive and significant effect of transformational leadership on academic culture accounted for a factor loading of 0.460 A non - significant effect of transformational leadership on self - engagement. A positive and significant effect of academic culture on self - engagement accounted for a factor loading of 0.765 .

\section{Recommendation}

The university needs to provide help and clear guidance for lecturer, a career development and an ideal compensation for lecturer. Head of study program as a leader needs to be flexible, improve communication and self - control while dealing with lecturer by keeping limitation between them and lecturer. The university urged to facilitate and support lecturer to be productive on research and publishing journal by independently or collaboratively. The university is expected to accommodate lecturer with a proper infrastructure in order to boost their focus and can be eager to do as much research as possible for the knowledge enrichment.

\section{REFERENCES}

Akhtar, N. A., Jalil, F., Farooq, M. S., Afzal, M., \& Awan, M. U. (2010). Effect of leadership and academic culture on implementation of self assessment manual in public sector universities of Pakistan. Journal of Quality and Technology Management, 6(1), 135-152.

Al-Sada, M., Al-Esmael, B., \& Faisal, M. N. (2017). Influence of organizational culture and leadership style on employee satisfaction, commitment and motivation in the educational sector in Qatar. EuroMed Journal of Business, 12(2), 163-188. https://doi.org/10.1108/EMJB-02-2016-0003

Almutairi, D. O. (2015). The mediating effects of organizational commitment on the relationship between transformational leadership style and job performance. International Journal of Business and Management, 11(1), 231. https://doi.org/10.5539/ijbm.v11n1p231 
Arifin, F., Troena, E. A., Djumahir, \& Rahayu, M. (2014). The Influence of organizational culture, leadership, and personal characteristics towards work engagement and its impacts on teacher's performance (A study on accredited high schools in Jakarta). International Journal of Business and Management Invention, 3(1), 20-29.

Arjunan, M., \& Balamurugan, M. (2013). Professional commitment of teachers working in tribal area schools. International Journal of Current Research and Development, 2(1), 65-74.

Attri, A. K., \& Devi, N. (2017). Relationship between professional commitment and self-efficacy of secondary teacher educators. International Journal of Advance Education and Research, 2(4), 42-44.

Awan, M. R., Mahmood, K., \& Idrees, H. (2014). Leadership style, culture and commitment: An analytical study of university libraries in Pakistan. Library Philosophy and Practice, 2014(1).

Awang, Z., Ahmad, J. H., \& Zin, N. M. (2010). Modelling job satisfaction and work commitment among lecturers: A case of UiTM Kelantan. Proceedings of the Regional Conference on Statistical Science (RCSS '10), (January 2015), 241-255. Retrieved from https://www.researchgate.net

Azizollah, A., Abolghasem, F., \& Mohammad Amin, D. (2015). The relationship between organizational culture and organizational commitment in Zahedan University of Medical Sciences. Global Journal of Health Science, 8(7), 195-202. https://doi.org/10.5539/gjhs.v8n7p195

Bae, S. H., Song, J. H., Park, S., \& Kim, H. K. (2013). Influential factors for teachers' creativity: Mutual impacts of leadership, work engagement and knowledge creation practices. Performance Improvement Quarterly, 26(3), 33-58. https://doi.org/10.1002/piq

Becker, T. E., Kernan, M. C., Clark, K. D., \& Klein, H. J. (2018). Dual commitments to organizations and professions: Different motivational pathways to productivity. Journal of Management, 44(3), 1202-1225. https://doi.org/10.1177/0149206315602532

Black, S. A. (2015). Qualities of effective leadership in higher education. Open Journal of Leadership, (4), 54-66. https://doi.org/10.4236/ojl.2015.42006

Brick, J. (2012). Academic Culture: A student's guide to studying in university (2nd ed.). Australia: Macmillan Publisher.

Bungai, J., \& Perdana, I. (2018). Evaluation of performance lecturer on implementing Tridharma college. IJER-INDONESIAN JOURNAL OF EDUCATIONAL REVIEW, 5(1), 174-182.

Chandel, P. (2019). Assessing the association of employee engagement with affective organizational commitment in higher education institutions. 04(02), 907-912.

Cho, V., \& Huang, X. (2012). Professional commitment, organizational commitment, and the intention to leave for professional advancement: An empirical study on IT professionals. Information Technology and People, 25(1), 31-54. https://doi.org/10.1108/09593841211204335

Colquitt, J. A., Lepine, J. A., \& Wesson, M. J. (2013). Organizational behaviour: Improving performance and commitment in the workplace (4th ed.). New York: McGraw-HIll Education.

Coman, A., \& Bonciu, C. (2016). Organizational culture in higher education: Learning from the best. 6(1), 135-145.

Darmawati. (2013). Pengaruh kepemimpinan transformasional, stres kerja dan kepuasan kerja terhadap kinerja dosen FKIP UMSU. Jurnal Educandum, 1(9), 51-66. Retrieved from http://digilib.unimed.ac.idpublicunimed-article-23719-darmawati.pdf

Dirwan, A. (2015). Pengaruh budaya organisasi dan komitmen terhadap kinerja dosen perguruan tinggi swasta. Jurnal Ilmu Pendidikan, 21(1), 1-8. Retrieved from http://www.surabaya.go.id/dinamis/?id=743

Dorenkamp, I., \& Ruhle, S. (2018). Work-life conflict, professional commitment, and job satisfaction among academics. Journal of Higher Education, 90(1), 56-84. https://doi.org/10.1080/00221546.2018.1484644

Eghlidi, F. F., \& Karimi, F. (2016). The relational between component of work engagement and organizational commitment of female employees of university. International Journal of Human Resource Studies, 6(3). https://doi.org/10.5296/ijhrs.v6i3.9689 
Endro, S., Budiyanto, \& Suhermin. (2017). The Influence of transformational leadership and personal value toward profession commitment and its impact on performance. International Journal of Education and Social Science, 4(4), 11-18.

Gill, S. P. K., \& Kaur, H. (2017). A study of professional commitment among senior secondary school teachers. International Journal of Advance Education and Research, 2(4), 253-257.

Gupta, M., \& Nain, I. (2015). An exploratory study of professional commitment among teacher educators working in B. Ed. Colleges. Bhartiyam International Journal of Education \& Research, 5(I), 40-53.

Habib, S., Aslam, S., Hussain, A., Yasmeen, S., \& Ibrahim, M. (2014). The impact of organizational culture on job satisfaction, employess commitment and turn over intention. Advances in Economics and Business, 2(6), 215-222. https://doi.org/10.13189/aeb.2014.020601

Halbesleben, J. R. B. (2010). A meta-analysis of work engagement: Relationships with burnout, demands, resources, and consequences. In A. B. Bakker \& M. P. Leiter (Eds.), Work engagement: A handbook of essential theory and research (pp. 102-117). New York: Psychology Press.

Hanaysha, J. (2016). Testing the effects of employee engagement, work environment and organizational learning on organizational commitment. Procedia - Social and Behavioral Sciences, 229, 289-297. https://doi.org/10.1016/j.sbspro.2016.07.139

Istambul, M. R. (2019). The impact of i-performance in changing the work culture of lecturers to increase the productivity of three pillars (tri dharma) of higher education in Indonesia. Universal Journal of Educational Research, 7(4), 15-21. https://doi.org/10.13189/ujer.2019.071403

Jabeen, A., Khan, S., \& Islam, S. Z.-U. (2019). Impact of leadership styles upon professional commitment. Global Regional Review, IV(III), 325-336. https://doi.org/10.31703/grr.2019(iv-iii).37

Jakubik, M., \& Vakkuri, M. (2015). The E-experience: Exploring employee engagement.

Kabeyi, M. J. B. (2018). Transformational vs transactional leadership with examples. The International Journal of Business \& Management, 6(5), 191-193. https://doi.org/10.4172/2169-

Kertiriasih, N. N. R., Sujana, I. W., \& Suardika, I. N. (2018). The effect of leadership style to job satisfaction, employee engagement and employee performance (Study at PT. Interbat, Bali, Nusra, and Ambon). International Journal of Contemporary Research and Review, 9(03), 20592-20600. https://doi.org/10.15520/ijcrr/2018/9/03/468

Klassen, R. M., Yerdelen, S., \& Durksen, T. L. (2013). Measuring teacher engagement: Development of the Engaged Teachers Scale (ETS). Frontline Learning Research, 1(2), 3352. https://doi.org/10.14786/flr.v1i2.44

Lacatus, M. L. (2013). Organizational culture in contemporary university. Procedia - Social and Behavioral Sciences, 76, 421-425. https://doi.org/10.1016/j.sbspro.2013.04.139

Li, C., \& Shi, K. (2008). The structure and measurement of transformational leadership in China. Frontiers of Business Research in China, 2(4), 571-590. https://doi.org/10.1007/s11782-0080032-5

Lomax, R. G. (2010). Structural equation modeling: Multisample covariance and mean structures. In G. R. Hancock, R. O. Mueller, \& L. M. Stapleton (Eds.), The reviewer's guide to quantitative methods in the social sciences (1st ed., pp. 385-394). New York: Taylor \& Francis e-Library.

Mitchell, R., Boyle, B., \& Von Stieglitz, S. (2018). Professional commitment and team effectiveness: A moderated mediation investigation of cognitive diversity and task conflict. Journal of Business and Psychology, 1-13. https://doi.org/10.1007/s10869-018-9550-0

Murniarti, E. (2014). Pengaruh penjaminan mutu, kepemimpinan transformasional, budaya akademik dan komitmen kerja terhadap kinerja dosen di kota Jambi. Jurnal Dinamika Pendidikan, 7(3), 149-156.

Nayak, R. R., \& Venkatraman, S. (2010). A pilot study into international students' academic culture: The context of Indian business students in an Australian university. E-Journal of 
Business Education \& Scholarship of Teaching, 4(2), 1-12.

Nazir, O., \& Islam, J. U. (2017). Enhancing organizational commitment and employee performance through employee engagement: An empirical check. South Asian Journal of Business Studies, 6(1), 98-114. https://doi.org/10.1108/SAJBS-04-2016-0036

Ng, T. W. H. (2017). Transformational leadership and performance outcomes: Analyses of multiple mediation pathways. Leadership Quarterly, 28(3), 385-417. https://doi.org/10.1016/j.leaqua.2016.11.008

Nikmah, D. N. (2015). Implementasi budaya akademik dan sikap ilmiah mahasiswa. Manajemen Pendidikan, 24(6), 483-490.

Northouse, P. G. (2016). Leadership: theory and practice (7th ed.). California: SAGE Publications, Inc.

Nur'aeni. (2011). Pengaruh motivasi, kompetensi dan komitmen terhadap kinerja dosen perguruan tinggi swasta di Kopertis wilayah II Palembang. Jurnal Manajeman Dan Bisnis, 1(2), 101129.

Ochugudu, Ipuele, A., \& Aondoaseer, A. F. (2013). Leadership styles as recipes for transformation. International Journal of Business and Management Review, 1(4), 35-53.

Ogbuanya, T. C., \& Chukwuedo, S. O. (2017). Job crafting - satisfaction relationship in electrical/electronic technology education programme: Do work engagement and commitment matter? Journal of Work and Organizational Psychology, 33, 165-173. https://doi.org/10.1016/j.rpto.2017.09.003

Para-González, L., Jiménez-Jiménez, D., \& Martínez-Lorente, A. R. (2018). Exploring the mediating effects between transformational leadership and organizational performance. Employee Relations, 40(2), 412-432. https://doi.org/10.1108/ER-10-2016-0190

Pielmus, C. (2016). An overview of academic culture. A study on law enforcement education. Social-Behavioural Sciences, 83(3), 220-229.

Purwana, D. (2015). The Effect of transformational leadership, academic culture and organizational health on managerial effectiveness : A study of an Indonesian public higher education institution. Review of Integrative Business \& Economics Research, 4(4), 367-380.

Raja, M. W. (2012). Does transformational leadership leads to higher employee work engagement: A study of Pakistani service sector firms. International Journal of Academic Research in Business and Social Sciences, 2(1), 2222-6990.

Rich, B. L., Lepine, J. A., \& Crawford, E. R. (2010). Job engagement: Antecedents and effects on job performance. Academy of Management Journal, 53(3), 617-635.

Rosser, V. J., \& Tabata, L. N. (2010). An examination of faculty work: Conceptual and theoritical frameworks in the literature. In J. C. Smart (Ed.), Higher Education: Handbook of Theory and Research (pp. 449-475). https://doi.org/10.1007/978-90-481-8598-6

Saks, A. M., \& Gruman, J. A. (2014). What do we really know about employee engagement? Human Resource Development Quarterly, 25(2), 155-182. https://doi.org/10.1002/hrdq

Schein, E. H., \& Schein, P. (2017). Organizational culture and leadership (5th ed.). https://doi.org/10.1017/CBO9781107415324.004

Selamat, N., Nordin, N., \& Adnan, A. A. (2013). Rekindle teacher's organizational commitment: The effect of transformational leadership behavior. Procedia - Social and Behavioral Sciences, 90, 566-574. https://doi.org/10.1016/j.sbspro.2013.07.127

Setyaningsih, S. (2017). Causal relationship model between variables using linear regression to improve professional commitment of lecturer. IOP Conf. Series: Materials Science and Engineering, 166, 1-8. https://doi.org/10.1088/1742-6596/755/1/011001

Shahdan, T. N. T., Ghani, M. F. A., \& Elham, F. (2012). Lecturers' commitment and students' academic achievement: viewed from teaching evaluation result. Journal of Education and Learning, 6(4), 207-214.

Shamina, H. (2014). Impact of job satisfaction on professional commitment in higher education. Galaxy International Interdiscplinary Research Journal, 2(2), 1-11.

Shen, X., \& Tian, X. (2012). Academic culture and campus culture of universities. Higher Education Studies, 2(2), 61-65. https://doi.org/10.5539/hes.v2n2p61

Shoaib, H., \& Khalid, I. (2017). Commitment with the teaching profession: Demographical view 
of teacher educators. Pakistan Journal of Education, 34(2), 19-36.

Shukla, S. (2014). Teaching competency, professional commitment and job satisfaction-A study of primary school teachers. IOSR Journal of Research \& Method in Education (IOSRJRME), 4(3), 44-64. https://doi.org/10.9790/7388-04324464

Siregar, Z., Lumbanraja, P., \& Salim, S. R. A. (2016). The implementation of Indonesia's three principles of higher education standard towards increasing competitiveness of local universities for ASEAN economic community. Pertanika Journal of Social Sciences and Humanities, 24(May), 1-12.

Suharti, L., \& Suliyanto, D. (2012). The effects of organizational culture and leadership style toward employee engagement and their impact toward employee loyalty. World Review of Business Research, 2(5), 128-139.

Sułkowski, Ł. (2016). Academic culture from the perspective of Polish Universities. PRZEDSIĘBIORCZOŚĆ I ZARZĄDZANIE, XVII(2), 7-21.

Sutjipto, Hidayat, R., \& Elizabeth, Y. (2014). Budaya akademik di Universitas Pakuan. Jurnal Ilmiah Pendidikan Universitas Pakuan, 6(2), 2-10.

Szelényi, K., \& Rhoads, R. A. (2013). Academic culture and citizenship in transitional societies: Case studies from China and Hungary. Higher Education, 66(4), 425-438. https://doi.org/10.1007/s10734-013-9614-z

Tansakul, J., Kamata, A., Patarapichayatham, C., \& Kanjanawasee, S. (2015). An evaluation of items and dimensional structure of a scale to measure teachers' professional commitment in Thailand. Asian Social Science, 11(16), 15-24. https://doi.org/10.5539/ass.v11n16p15

Thoker, A. A. (2017). Professional commitment of Government and Private School teachers with special reference to their rural urban dichotomy. International Journal of Humanities Social Sciences and Education, 4(6), 95-103. https://doi.org/http://dx.doi.org/10.20431/23490381.0406013

Tims, M., Bakker, A. B., \& Xanthopoulou, D. (2011). Do transformational leaders enhance their followers' daily work engagement? Leadership Quarterly, 22(1), 121-131. https://doi.org/10.1016/j.leaqua.2010.12.011

Truss, C., Shantz, A., Soane, E., Alfes, K., \& Delbridge, R. (2013). Employee engagement, organisational performance and individual well-being: exploring the evidence, developing the theory. The International Journal of Human Resource Management, 24(14), 2657-2669. https://doi.org/10.1080/09585192.2011.552282

Widawati, L., Styani, Y., \& Nadya, D. (2010). Profil komitmen dosen dalam kegiatan tridarma perguruan tinggi. Mimbar, XXVI(1), 93-104.

Wood, M., \& Su, F. (2017). What makes an excellent lecturer? Academics' perspectives on the discourse of 'teaching excellence' in higher education. Teaching in Higher Education, 22(4), 451-466. https://doi.org/10.1080/13562517.2017.1301911

Xiao, J., \& Wilkins, S. (2015). The effects of lecturer commitment on student perceptions of teaching quality and student satisfaction in Chinese higher education. Journal of Higher Education Policy \& Management, 37(1), 98-110. https://doi.org/10.1080/1360080X.2014.992092

Yahaya, R., \& Ebrahim, F. (2016). Leadership styles and organizational commitment: literature review. Journal of Management Development, 35(2), 190-216. https://doi.org/10.1108/JMD01-2015-0004

Yalabik, Z. Y., van Rossenberg, Y., Kinnie, N., \& Swart, J. (2015). Engaged and committed? The relationship between work engagement and commitment in professional service firms. International Journal of Human Resource Management, 26(12), 1-20. https://doi.org/10.1080/09585192.2014.953972

$\mathrm{Yu}, \mathrm{B}$. (2013). The influence study of transformational leadership in university on teacher 's organizational commitment: The construction and verification of a theoretical model. $\begin{array}{llll}\text { Canadian Social } & \text { Science, } & \text { 126-137. }\end{array}$ https://doi.org/10.3968/j.css.1923669720130904.5795
Yukl,
G. (2013).
Leadership
in
organizations
(8th
ed.). https://doi.org/10.1017/CBO9781107415324.004 
Zhu, C., Devos, G., \& Li, Y. (2011). Teacher perceptions of school culture and their organizational commitment and well-being in a Chinese school. Asia Pacific Education Review, 12(2), 319328. https://doi.org/10.1007/s12564-011-9146-0 